\title{
REACTIONS OF HUMAN SUBJECTS TO THE INJECTION OF PURIFIED TYPE SPECIFIC PNEUMOCOCCUS POLYSACCHARIDES ${ }^{1}$
}

\author{
By MAXWELL FINLAND AND JOHN W. BROWN \\ (From the Thorndike Memorial Laboratory, Second and Fourth Medical Services (Harvard), \\ and the Department of Medicine, Harvard Medical School, Boston)
}

(Received for publication March 21, 1938)

By subjecting pneumococcus filtrates to ultrafiltration followed by repeated fractional precipitation with alcohol, Wadsworth and Brown (1) have obtained good yields of type-specific and species-specific polysaccharides in a relatively high state of purification. This report deals with the local reactions and the type-specific antibody response of non-pneumonic human subjects to injections of specific polysaccharides of Types I, IV, V, VII, and XIV pneumococci prepared by this method.

Tillett and Francis (2) described the occurrence of typical immediate wheal and erythema reactions to the homologous type-specific capsular carbohydrates when injected intradermally in patients convalescing from pneumonia. These reactions were associated with the finding of antibodies for the same type of pneumococcus in the patient's serum. With the so-called nucleoprotein of the pneumococcus they elicited a delayed tuberculin type of reaction after recovery, but circulating precipitins for this material were demonstrated during the disease as well as in convalescence. Francis and Tillett (3) further demonstrated that pneumonia patients repeatedly tested with solutions of Types I, II, and III specific polysaccharides develop antibodies for the types of carbohydrate injected regardless of the infecting type of pneumococcus. Their findings were confirmed in this laboratory $(4,5)$ and also by Alston, Galbraith, and Stewart (6). Similar skin reactions were also elicited with varying frequency, using polysaccharides prepared by the same and by other methods, in normal subjects and in hospital subjects without pneumonia or recent intracutaneous injections $(7,8,9,10)$. In such subjects, positive reactions to the initial injections were not correlated with the presence of circulating antibodies $(7,8$, $9,10)$ but the development of antibodies for the homologous pneumococcus type was stimulated by a single or by multiple intracutaneous injections $(8,9,11,12)$.

Alston and Lowden (10), using Type I and Type II specific polysaccharides prepared by the methods of Heidelberger, Sia, and Kendall (13) and of Heidelberger and Avery (14), respectively, observed in normal sub-

\footnotetext{
1 This study was aided, in part, by a grant given in honor of Francis Weld Peabody by the Ella Sachs Plotz Foundation.
}

jects a secondary cutaneous reaction consisting of redness, edema, and tenderness occurring in 2 to 5 hours and lasting 8 to 48 hours. A similar reaction had also been described by Finland and Sutliff (4) in occasional patients recovering from pneumonia in whom the reactions, induced by similar polysaccharides, were typespecific and began as a typical but intense immediate wheal and erythema. Similar reactions, both with and without the characteristic immediate phase were also noted in non-pneumonic subjects tested with autolysates from virulent and from avirulent strains (7).

Tillett and Francis (15) and later Ash (16) demonstrated precipitins for the somatic, species-specific, carbohydrate, the so-called $C$ fraction of Tillett, Goebel, and Avery (17), in the febrile stage of pneumonia and of many other acute infections but not after recovery from these diseases. Francis and Abernethy (18) reported immediate and delayed reactions, similar to those described above, which they obtained with the $\mathrm{C}$ fraction during the height of pneumonia and other febrile illnesses but not during convalescence and not in cases having a fatal termination.

Differences in antigenic activity of type-specific carbohydrate substances derived in different ways from the same type of pneumococcus have been observed by many workers (19 to 27 inc.). Wadsworth and Brown (19) found that all of their so-called cellular carbohydrates contain phosphorus and nitrogen, produce purpura in mice, and differ from the corresponding soluble specific substance prepared by the earlier methods of Heidelberger, Avery, and others in their reaction with immune serums and in the response following animal inoculation. Some differences were also noted between their cellular carbohydrate derived from their atypical avirulent pneumococcus and the $C$ fraction of Tillett, Goebel, and Avery (17). Finland and Dowling (9) studied the reactions of human subjects to some of these materials. They found only minor differences in the antibody response elicited by the polysaccharides derived by different methods from the same type of pneumococcus. Delayed cutaneous reactions occurred only with the cellular carbohydrates. The findings with the cellular carbohydrates of the atypical Type I pneumococcus were similar to those elicited by Francis and Abernethy with the " $\mathrm{C}$ " fraction (18).

Avery and Goebel (28) ascribed most of the differences in the Type I preparations to changes resulting from the treatment of the polysaccharides with alkali which deprives them of an acetyl group. Such treatment 
was avoided on the present preparations (1). Francis (12) showed that both the acetylated and the deacetylated forms of the Type I polysaccharide were capable of stimulating the production of homologous antibody in normal human subjects after 3 intracutaneous injections of 0.01 mgm. given one week apart. Felton and Prescott also found the antigenicity of Type I polysaccharides to be independent of the acetyl group (29).

In the various studies mentioned, the materials were obtained from Types I, II, and III pneumococci and were usually given in single or repeated intracutaneous injections of $0.01 \mathrm{mgm}$. to $0.05 \mathrm{mgm}$. amounts. The Types I and II preparations gave the most characteristic reaction, the Type I preparations were most regularly antigenic and the Type III preparations gave the most irregular results. Felton, Sutliff, and Steele (30) gave $2.0 \mathrm{mgm}$. doses subcutaneously using a number of soluble antigens derived by various methods from Types I and II pneumococci. Local reactions consisting of swelling and redness occurred at the site of the subcutaneous injections and usually began to subside in 48 hours. In contrast to the findings of other workers, who elicited only a homologous type-specific antibody response, they demonstrated, in human subjects, an increase in protective titer of the serum for both the homologous and the heterologous type, a finding similar to that recorded by Day (31) in rabbits.

With a highly purified specific carbohydrate of Pneumococcus Type VIII, Finland and Ruegsegger (32) obtained high titers of the homologous antibody with great regularity by injecting $1.0 \mathrm{mgm}$. subcutaneously. Various preparations of Type III pneumococcus polysaccharide given in the same manner produced antibodies for the homologous type with less regularity and in lower titers. Occasional subjects developed antibodies against the heterologous but related type (33), after receiving either the Type III or the Type VIII carbohydrates. Ruegsegger and Finland (34) also investigated the antibody stimulating efficacy of various doses of Type VIII polysaccharide when given by different routes and found the optimum dose to be $1.0 \mathrm{mgm}$. given subcutaneously. When smaller doses were used, however, they were more effective when given intracutaneously.

\section{MATERIALS AND METHODS}

The pneumococcus polysaccharides were prepared and furnished in dry form by Dr. Rachel Brown of the Division of Laboratories and Research, New York State Department of Health. The analytical data concerning these preparations were also furnished by her and are given in Table I. Stock solutions of these preparations were made up with sterile 0.85 per cent sodium chloride solution to contain $4 \mathrm{mgm}$. per cubic centimeter.

The subjects included normal young adults from the hospital or laboratory staff, medical students, and adult hospital patients without recent febrile illnesses. For the subcutaneous injections, $1 \mathrm{mgm}$. of polysaccharide contained in $1 \mathrm{cc}$. of saline was injected under the skin overlying the deltoid muscle. For the intracutaneous in-
TABLE I

Analytical data concerning the polysaccharide preparations used *

\begin{tabular}{|c|c|c|c|c|c|c|c|}
\hline Type & $\begin{array}{l}\text { Prepa- } \\
\text { ration } \\
\text { number }\end{array}$ & $\begin{array}{c}\text { Total } \\
\text { nitro- } \\
\text { gen }\end{array}$ & $\begin{array}{c}\text { Amino } \\
\text { nitro- } \\
\text { gen }\end{array}$ & $\mathbf{P}$ & Acetyl & Ash & $\begin{array}{c}\text { Mois- } \\
\text { ture }\end{array}$ \\
\hline & & $\begin{array}{l}\text { per } \\
\text { cent }\end{array}$ & $\begin{array}{l}\text { per } \\
\text { cent }\end{array}$ & $\begin{array}{l}\text { per } \\
\text { cent }\end{array}$ & $\begin{array}{l}\text { per } \\
\text { cent }\end{array}$ & $\begin{array}{l}\text { per } \\
\text { cent }\end{array}$ & $\begin{array}{l}\text { per } \\
\text { cent }\end{array}$ \\
\hline $\begin{array}{r}\text { II... } \\
\text { IV.... } \\
\text { VII... } \\
\text { XIV... }\end{array}$ & $\begin{array}{r}14 \\
1 \\
7 \\
7 \\
1\end{array}$ & $\begin{array}{l}5.34 \\
4.99 \\
5.37 \\
5.59 \\
2.83\end{array}$ & $\begin{array}{l}0.35 \\
0.18 \\
0.07 \\
\\
0.04\end{array}$ & $\begin{array}{l}0.07 \\
1.05 \\
\\
0.24\end{array}$ & $\begin{array}{r}8.17 \\
12.08\end{array}$ & $\begin{array}{l}4.20 \\
5.84 \\
3.93 \\
2.84 \\
1.23\end{array}$ & $\begin{array}{r}6.28 \\
10.48 \\
5.94 \\
6.96 \\
10.65\end{array}$ \\
\hline
\end{tabular}

* These materials and the data concerning them were supplied by Dr. Rachel Brown.

The percentages are given for the weight of the substances including the moisture.

jections, $0.1 \mathrm{cc}$. of solution containing $0.01 \mathrm{mgm}$. of carbohydrate was given into the skin of the flexor surface of the forearm, and this was controlled with a similar injection of the same freshly prepared sterile physiological saline as was used in making the required dilution. No preservative and no heat were employed but the solutions used were cultured and found to be sterile. Notes were made of the local and general reactions to the subcutaneous injections. The intracutaneous injections were read at one-half hour and again at 18 to 24 hours and were observed at other intervals when indicated. Most of the cutaneous reactions noted with the present materials were similar to those already described $(2,5,9,10,18)$ except in degree. They varied in frequency and intensity with the different preparations. Some of the unusual reactions will be considered with each, in turn.

Venous blood for serological tests was obtained from each subject before and 10 to 12 days after the injection and occasionally at other intervals. Agglutination tests were carried out with equal volumes of serum dilutions and of formalinized suspensions of actively growing pneumococci containing approximately 1 billion diplococci per cubic centimeter. These were incubated for 2 hours at $37^{\circ} \mathrm{C}$. and read after storage in the ice box overnight. The highest dilution of serum showing floccular agglutination was considered the end-point. Protection tests were carried out with $0.2 \mathrm{cc}$. of serum, and decimal dilutions of culture injected simultaneously. The virulence of the cultures was maintained by daily mouse passage.

\section{Results with Type I SSS, Preparation Number 14}

The local reactions and the results of the serological tests in 4 subjects injected subcutaneously and in 6 injected intracutaneously are listed in Table II. Briefly, the subcutaneous injections gave only slight local reactions in most instances but were regularly followed by a good antibody response as evidenced by the positive immediate 
TABLE II

Response to injection of soluble specific substance Type I, Preparation Number 14

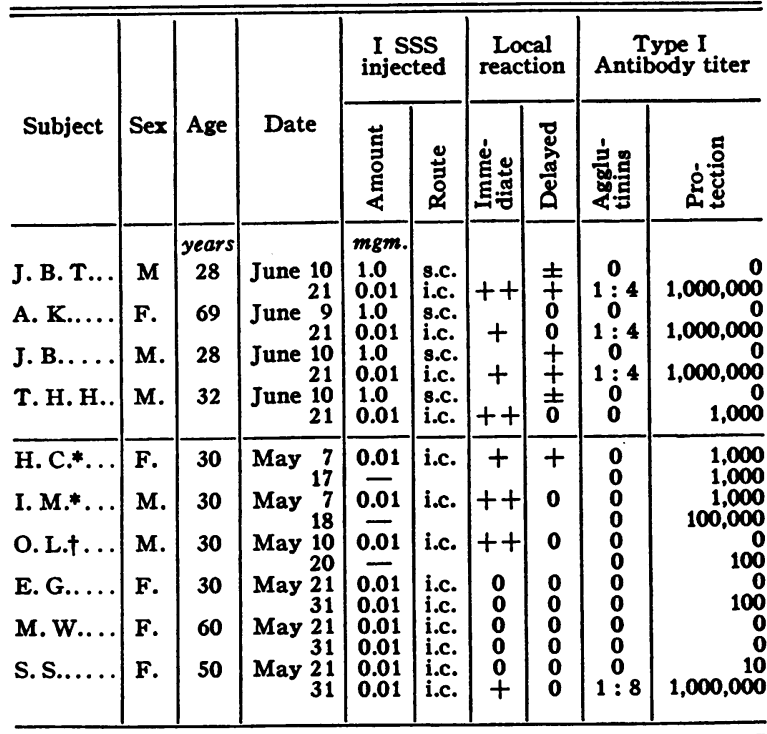

* These 2 subjects were healthy carriers of Type I pneumococci 10 days prior to the intracutaneous injection (cf. 35).

$\dagger$ Carrier of Type II pneumococci 2 weeks previously.

\section{Explanation of Tables II to Vinc.}

Route: s.c. $=$ subcutaneous; i.c. $=$ intracutaneous.

Local reactions:

Following subcutaneous injections (delayed).

$\pm=$ tenderness only.

$+=$ tenderness and swelling less than $2 \mathrm{~cm}$.

$++=$ redness, tenderness, swelling more than $3 \mathrm{~cm}$., or with constitutional symptoms.

Immediate intracutaneous reactions.

$\pm=$ wheal larger than control, without pseudopods, but with surrounding erythema.

$+=$ wheal well defined with pseudopods and bright erythema $2.0 \mathrm{~cm}$. or more.

$+t=$ edematous wheal more than $1.5 \mathrm{~cm}$., definite pseudopods, and bright erythema more than $3.0 \mathrm{~cm}$.

Delayed intracutaneous reactions ( 8 to 24 hours).

$\pm=0.5$ to $1.0 \mathrm{~cm}$. redness with slight tenderness.

$+=1.0 \mathrm{~cm}$. or greater redness and tenderness.

$++=$ local edema $3 \mathrm{~cm}$. or more.

Agglutinins: $1: 2,1: 4$, etc. = highest serum dilution showing floccular agglutination.

Protection: largest number of fatal doses which mice survived with simultaneous injections of $0.2 \mathrm{cc}$. of serum.

$-=$ Not done.

I, V, etc. = Type I, Type V, etc.

SSS $^{\prime}=$ soluble specific substance.

cutaneous reaction and the high titer of mouse protective antibodies. A comparable response to the single intracutaneous injection was obtained in only one subject. The others developed antibodies of low titer or increased previously existing levels only slightly if at all.
Tests for antibodies against heterologous types of pneumococci were done on the sera of 5 subjects, using Types II, V, and VIII pneumococci. No antibodies developed against these types.

\section{Results with Type V SSS, Preparation Number 7}

This material was given to 5 subjects subcutaneously and to 6 intracutaneously. The data for these subjects are given in Table III. The

TABLE III $\dagger$

Effect of injection of soluble specific substance Type V, Preparation Number 7

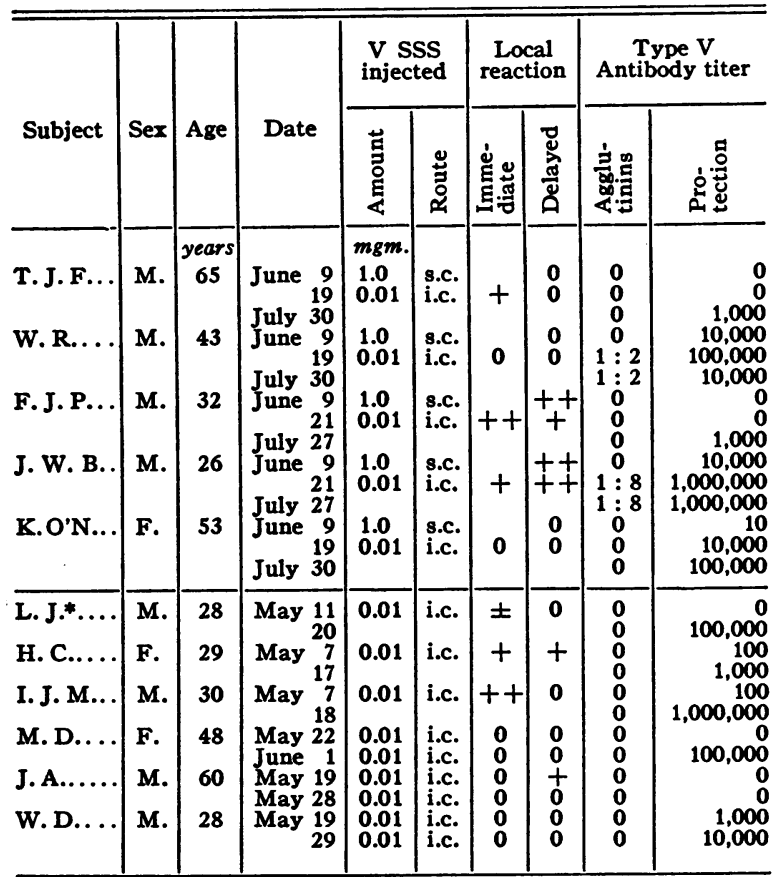

† See Table II for explanation of symbols.

* Carrier of Type VIII pneumococci on April 27 ; serum protected against $1,000,000$ fatal doses Type VIII pneumococci on that day (cf. 35).

type-specific antibody response to this preparation was not as good as in the case of the Type I material, and the local reactions were irregular. Positive cutaneous reactions did not correlate with the antibody findings. Some of the subjects who showed no protective antibody 10 and 12 days, respectively, after the subcutaneous injection later developed such antibodies presumably aided by the additional stimulus of the intracutaneous injection used for the tests. Agglutinins appeared in 2 subjects only, and they had a rela- 
tively high titer of protective antibody in the control serum.

Tests for protective antibody against the related Type II pneumococci (36) were done on all the sera of the subcutaneously injected subjects and none developed antibodies for this type.

\section{Results with Type VII SSS, Preparation Number 7}

This preparation was given to 5 subjects subcutaneously and to a similar number intracutaneously. The former all showed some local reaction to the injection. They all later gave strongly positive intradermal tests and, with one exception, developed agglutinins in their sera. The latter all failed to show an increase in the homologous antibody titer. The results of the various tests are listed in Table IV.

TABLE IV $\dagger$

Effect of injection of soluble specific substance Type VII, Preparation Number 7

\begin{tabular}{|c|c|c|c|c|c|c|c|c|c|}
\hline \multirow[b]{2}{*}{ Subject } & \multirow[b]{2}{*}{ Sex } & \multirow[b]{2}{*}{ Age } & \multirow[b]{2}{*}{ Date } & \multicolumn{2}{|c|}{$\begin{array}{l}\text { VII SSS } \\
\text { injected }\end{array}$} & \multicolumn{2}{|c|}{$\begin{array}{l}\text { Local } \\
\text { reaction }\end{array}$} & \multicolumn{2}{|c|}{$\begin{array}{c}\text { Type VII } \\
\text { Antibody titer }\end{array}$} \\
\hline & & & & 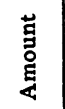 & 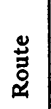 & 悹萝 & 马્d & 常量 & 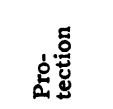 \\
\hline $\begin{array}{l}\text { W. B... } \\
\text { M. L.... } \\
\text { M. T... } \\
\text { J. M. H. . } \\
\text { R. W. H. }\end{array}$ & $\begin{array}{l}\text { M. } \\
\text { M. } \\
\text { M. } \\
\text { M. } \\
\text { M. }\end{array}$ & $\begin{array}{c}\text { years } \\
28 \\
24 \\
24 \\
30 \\
28\end{array}$ & $\begin{array}{lr}\text { June } & 10 \\
& 21 \\
\text { June } & 10 \\
& 21 \\
\text { June } & 10 \\
& 21 \\
\text { June } & 9 \\
& 21 \\
& 28 \\
\text { July } & 28 \\
\text { June } & 10 \\
& 21 \\
\text { July } & 28\end{array}$ & $\begin{array}{l}m g m . \\
1.0 \\
0.01 \\
1.0 \\
0.01 \\
1.0 \\
0.01 \\
1.0 \\
0.01 \\
\overline{1.0} \\
0.01 \\
-\end{array}$ & $\begin{array}{l}\text { s.c. } \\
\text { i.c. } \\
\text { s.c. } \\
\text { i.c. } \\
\text { s.c. } \\
\text { i.c. } \\
\text { s.c. } \\
\text { i.c. } \\
\text { s.c. } \\
\text { i.c. }\end{array}$ & $\begin{array}{l}++ \\
++ \\
++ \\
++\end{array}$ & $\begin{array}{c}+ \\
+ \\
+ \\
0 \\
+ \\
0 \\
\pm \\
0 \\
++ \\
\pm\end{array}$ & $\begin{array}{c}1: 4^{*} \\
1: 32 \\
1: 8^{*} \\
1: 8^{*} \\
0 \\
1: 4 \\
0 \\
1: 16 \\
1: 16 \\
0 \\
1: 8 \\
1: 4\end{array}$ & \\
\hline $\begin{array}{l}\text { C. G.... } \\
\text { C. V.... } \\
\text { E. C.... } \\
\text { W. D... } \\
\text { A. F.... }\end{array}$ & $\begin{array}{l}\text { M. } \\
\text { M. } \\
\text { M. } \\
\text { M. } \\
\text { M. }\end{array}$ & $\begin{array}{l}64 \\
54 \\
21 \\
48 \\
57\end{array}$ & \begin{tabular}{|rr} 
April & 15 \\
& 24 \\
May & 18 \\
& 28 \\
May & 18 \\
& 28 \\
May & 18 \\
& 28 \\
May 18 \\
28
\end{tabular} & $\begin{array}{l}0.01 \\
0.01 \\
0.01 \\
0.01 \\
0.01 \\
0.01 \\
0.01 \\
0.01 \\
0.01\end{array}$ & $\begin{array}{l}\text { i.c. } \\
\text { i.c. } \\
\text { i.c. } \\
\text { i.c. } \\
\text { i.c. } \\
\text { i.c. } \\
\text { i.c. } \\
\text { i.c. } \\
\text { i.c. }\end{array}$ & $\begin{array}{c} \pm \\
++ \\
+ \pm \\
0 \\
0 \\
+ \\
0 \\
+ \\
+\end{array}$ & $\begin{array}{l}0 \\
0 \\
0 \\
0 \\
0 \\
0 \\
+ \\
+\end{array}$ & $\mid \begin{array}{ll}1 & : 2 \\
1 & : 2 \\
1 & : 2 * \\
1 & : 2 * \\
0 & \\
0 \\
1: 2 * \\
0 \\
1: 4 \\
1: 4\end{array}$ & $\begin{array}{r}100,000 \\
10,000 \\
1,000,000 \\
1,000,000 \\
100,000 \\
1,000 \\
100,000 \\
100,000 \\
1,000,000 \\
10,000,000\end{array}$ \\
\hline
\end{tabular}

* Fine floccular agglutination.

† See Table II for explanation of symbols.

Mouse protection tests with the Type VII pneumococcus and human sera have not been entirely satisfactory because of the irregular virulence of this organism and the high titers of protection found in the sera of most normal individuals, and even during the acute stage of pneumonia due to this type (37). Previous studies indicated that the protection test is a more delicate index of the development of small amounts of specific antibody than either the agglutination test or the cutaneous reaction to type-specific polysaccharides (4). In the present study, therefore, Type VII protection tests were carried out only with the sera of the intracutaneously injected subjects. All showed protection in the control sera but no significant increases in titer appeared in the later ones.

The sera of each of the subjects were tested for the development of antibodies against one or more heterologous types of pneumococci. Types I, II, IV, V, and VIII pneumococci were used in agglutination and mouse protection tests and all yielded negative results.

\section{Results with Type IV SSS, Preparation Number 1 and Type XIV SSS, Preparation Number 1}

Two series of observations were made with these preparations. In one group, each subject was given a subcutaneous injection of one of the preparations. This was followed in about 2 weeks by intracutaneous tests with both preparations, and the blood was studied just before and about 3 weeks after these intradermal tests to determine the antigenic effects of both the subcutaneous injection and of the skin test injections. The data for this group are shown in Table VA. In the second group, one of the preparations was given intracutaneously and skin tests were done later with both. The results in this group are given in Table $\mathrm{V} B$.

Briefly, the Type IV preparation gave local reactions regularly when injected subcutaneously and frequently to an initial intracutaneous injection, whereas the Type XIV preparation was free of such reactions. Both preparations gave nonspecific reactions to later injections. Both gave good antibody responses for the homologous pneumococcus type. The subcutaneous and intracutaneous injections were about equally effective. Protection tests were not done with the Type XIV pneumococcus because none of the strains available could be raised in virulence sufficiently to be satisfactory for this purpose.

Agglutinins and mouse protection tests were also carried out with Types II, V, VIII, and XI pneumococci on these sera. Only 3 subjects developed protective antibody in their sera against 
heterologous pneumococcus types: Subjects T. D. and W. C. developed protection against 10,000 and 100 lethal doses, respectively, of Type II pneumococci and Subject M. McR. developed protection against 100,000 fatal doses of Type V pneumococci.

An unusually severe reaction to the intracutaneous injection of Type IV SSS was observed in Subject J. V. (Table $\mathrm{V} A$ ). A yellow edematous wheal appeared almost immediately and increased for 40 minutes to a maximum diameter of $2.5 \mathrm{~cm}$. It had numerous stubby pseudopods and was surrounded by an area of intense erythema $8.5 \mathrm{~cm}$. in diameter. The wheal gradually blended with the surrounding erythema to form a soft puffed up area elevated about $2.5 \mathrm{~cm}$. in the center which involved half the flexor surface of the forearm and was exquisitely tender. There was no redness or lymphangitis visible, but one of the axillary nodes became enlarged and tender. The entire reaction subsided in about 24 hours, and it was not accompanied by any febrile reaction. The initial subcutaneous injection of the same material had given rise to a red, tender swelling about 6 $\mathrm{cm}$. in diameter. In a second subject, G. P. (Table VB), the second intracutaneous injection of the same material gave a very similar reaction except that an epitrochlear node was enlarged in this instance.

TABLE $\mathbf{v} \dagger$

Effect of injection of Type IV SSS, Preparation 1, and Type XIV SSS, Preparation 1

$A$. Subcutaneous injection of one followed by intracutaneous injection of both

\begin{tabular}{|c|c|c|c|c|c|c|c|c|c|c|c|c|c|c|}
\hline \multirow{3}{*}{ Subject } & \multirow{3}{*}{$\operatorname{Sex}$} & \multirow{3}{*}{ Age } & \multirow{3}{*}{ Date } & \multicolumn{4}{|c|}{ Type IV SSS injected } & \multicolumn{4}{|c|}{ Type XIV Ss' injected } & \multicolumn{3}{|c|}{ Antibodies } \\
\hline & & & & \multirow{2}{*}{ Amount } & \multirow{2}{*}{ Route } & \multicolumn{2}{|c|}{ Local reaction } & \multirow{2}{*}{ Amount } & \multirow{2}{*}{ Route } & \multicolumn{2}{|c|}{ Local reaction } & \multicolumn{2}{|c|}{ Agglutinins } & \multirow{2}{*}{$\begin{array}{l}\text { Protection } \\
\text { Type IV }\end{array}$} \\
\hline & & & & & & Imme- & Delayed & & & $\begin{array}{c}\text { Imme- } \\
\text { diate }\end{array}$ & Delayed & Type IV & Type XIV & \\
\hline A. B.... & F. & $\begin{array}{c}\text { years } \\
63\end{array}$ & $\begin{array}{lr}\text { June } & 26 \\
\text { July } & 6 \\
\text { Aug. } & 13\end{array}$ & $\begin{array}{l}m g m . \\
1.0 \\
0.01\end{array}$ & $\begin{array}{l}\text { s.c. } \\
\text { i.c. }\end{array}$ & 0 & ++ & $\frac{m g m .}{0.01}$ & i.c. & 0 & 0 & $\begin{array}{l}0 \\
0 \\
0\end{array}$ & $\begin{array}{c}0 \\
0 \\
1: 2\end{array}$ & $\begin{array}{l}0 \\
0 \\
0\end{array}$ \\
\hline J. C.*... & M. & 44 & $\begin{array}{l}\text { June } \\
\text { July }\end{array}$ & 1.0 & s.c. & & + & - & & & & $\begin{array}{c}0 \\
1: 64\end{array}$ & $\begin{array}{l}\mathbf{0} \\
\mathbf{0}\end{array}$ & $\stackrel{0}{100,000}$ \\
\hline H. L.* .. & M. & 51 & $\begin{array}{lr}\text { June } & 24 \\
\text { July } & 6 \\
\text { Aug. } & 3\end{array}$ & 1.0 & s.c. & & + & - & & & & $\begin{array}{l}0 \\
1: 4 \\
1: 4\end{array}$ & $\begin{array}{l}0 \\
1: 4 \\
1: 4\end{array}$ & $\begin{array}{c}0 \\
10,000 \\
1,000\end{array}$ \\
\hline J. V...... & F. & 48 & $\begin{array}{lr}\text { June } & 24 \\
\text { July } & 6 \\
\text { July } & 31 \\
\text { Nov. } & 9\end{array}$ & $\begin{array}{l}1.0 \\
0.01\end{array}$ & $\begin{array}{l}\text { s.c. } \\
\text { i.c. }\end{array}$ & ++ & $\begin{array}{l}+t \\
+t\end{array}$ & $\overline{0.01}$ & i.c. & \pm & 0 & $\begin{array}{l}0 \\
1: 64 \\
1: 32 \\
1: 32\end{array}$ & $\begin{array}{l}0 \\
0 \\
1: 16 \\
1: 8\end{array}$ & $\begin{array}{c}0 \\
100,000 \\
1,000,000 \\
1,000,000\end{array}$ \\
\hline W. C..... & M. & 51 & $\begin{array}{lr}\text { June } & 24 \\
\text { July } & 6 \\
\text { July } & 29\end{array}$ & $\begin{array}{l}1.0 \\
0.01\end{array}$ & $\begin{array}{l}\text { s.c. } \\
\text { i.c. }\end{array}$ & ++ & $\begin{array}{l}++ \\
++\end{array}$ & 0.01 & i.c. & + & 0 & $\begin{array}{l}0 \\
1: 8 \\
1: 32\end{array}$ & $\begin{array}{c}0 \\
0 \\
1: 2\end{array}$ & $\begin{array}{c}0 \\
1,000,000 \\
10,000,000\end{array}$ \\
\hline R. E. M.. & M. & 28 & $\begin{array}{lr}\text { June } & 24 \\
\text { July } & 7 \\
\text { July } & 27\end{array}$ & $\overline{0.01}$ & i.c. & + & 0 & $\begin{array}{l}1.0 \\
0.01\end{array}$ & $\begin{array}{l}\text { s.c. } \\
\text { i.c. }\end{array}$ & ++ & $\begin{array}{c}0 \\
++\end{array}$ & $\begin{array}{c}0 \\
0 \\
1: 8\end{array}$ & $\begin{array}{l}0 \\
1: 32 \\
1: 32\end{array}$ & $\begin{array}{c}100 \\
100 \\
1,000,000\end{array}$ \\
\hline T. D.... & M. & 27 & $\begin{array}{l}\text { June } 28 \\
\text { July } 10 \\
\text { July } 27\end{array}$ & 0.01 & i.c. & ++ & $+t$ & $\begin{array}{l}1.0 \\
0.01\end{array}$ & $\begin{array}{l}\text { s.c. } \\
\text { i.c. }\end{array}$ & ++ & $\begin{array}{c}0 \\
++\end{array}$ & $\begin{array}{c}0 \\
0 \\
1: 2\end{array}$ & $\begin{array}{c}0 \\
1: 2 \\
1: 2\end{array}$ & $\begin{array}{c}0 \\
10 \\
100,000\end{array}$ \\
\hline M. McR. & M. & 27 & $\begin{array}{lr}\text { June } & 24 \\
\text { June } & 7 \\
\text { July } & 27\end{array}$ & 0.01 & i.c. & \pm & $\mathbf{0}$ & $\begin{array}{l}1.0 \\
0.01\end{array}$ & $\begin{array}{l}\text { s.c. } \\
\text { i.c. }\end{array}$ & + & $\begin{array}{l}\mathbf{0} \\
0\end{array}$ & $\begin{array}{c}0 \\
0 \\
1: 16\end{array}$ & $\begin{array}{l}0 \\
1: 16 \\
1: 8\end{array}$ & $\begin{array}{c}1,000 \\
1,000 \\
1,000,000\end{array}$ \\
\hline F.E... & M. & 28 & $\begin{array}{lr}\text { June } & 24 \\
\text { July } & 7 \\
\text { July } & 27\end{array}$ & 0.01 & i.c. & 0 & $\mathbf{0}$ & $\begin{array}{l}1.0 \\
0.01\end{array}$ & $\begin{array}{l}\text { s.c. } \\
\text { i.c. }\end{array}$ & 0 & $\begin{array}{l}\mathbf{0} \\
\mathbf{0}\end{array}$ & $\begin{array}{c}0 \\
0 \\
1: 4\end{array}$ & $\begin{array}{l}0 \\
1: 4 \\
1: 4\end{array}$ & $\begin{array}{c}0 \\
0 \\
100,000\end{array}$ \\
\hline H. S. . & M. & 26 & $\begin{array}{lr}\text { June } & 24 \\
\text { July } & 9 \\
\text { Aug. } & 4 \\
\text { Oct. } & 26\end{array}$ & 0.01 & i.c. & + & 0 & $\begin{array}{l}1.0 \\
0.01\end{array}$ & $\begin{array}{l}\text { 8.c. } \\
\text { i.c. }\end{array}$ & + & $\begin{array}{l}\mathbf{0} \\
\mathbf{0}\end{array}$ & $\begin{array}{c}0 \\
0 \\
1: 8 \\
1: 16\end{array}$ & $\begin{array}{l}0 \\
1: 16 \\
1: 16 \\
1: 32\end{array}$ & $\begin{array}{c}0 \\
0 \\
10,000 \\
100,000\end{array}$ \\
\hline
\end{tabular}


TABLE v-Continued

$B$. Intracutaneous injection

\begin{tabular}{|c|c|c|c|c|c|c|c|c|c|c|}
\hline \multirow{3}{*}{ Subject } & \multirow{3}{*}{ Sex } & \multirow{3}{*}{ Age } & \multirow{3}{*}{ Date } & \multicolumn{4}{|c|}{$\begin{array}{l}\text { Reaction to } 0.01 \text { mgm. SSS injected } \\
\text { intracutaneously }\end{array}$} & \multicolumn{3}{|c|}{ Antibodies } \\
\hline & & & & \multicolumn{2}{|c|}{ Type IV } & \multicolumn{2}{|c|}{ Type XIV } & \multicolumn{2}{|c|}{ Agglutinins } & \multirow{2}{*}{$\begin{array}{c}\text { Protection } \\
\text { Type IV }\end{array}$} \\
\hline & & & & Immediate & Delayed & Immediate & Delayed & Type IV & Type XIV & \\
\hline F. R. R. & M. & $\begin{array}{c}\text { years } \\
41\end{array}$ & $\begin{array}{l}\text { July } 28 \\
\text { Aug. } 9\end{array}$ & $\stackrel{0}{+}$ & $\stackrel{0}{++}$ & $\overline{ \pm}$ & $\overline{0}$ & $\stackrel{0}{1: 16}$ & $\begin{array}{l}\mathbf{0} \\
\mathbf{0}\end{array}$ & $\begin{array}{c}0 \\
10,000,000\end{array}$ \\
\hline G. P. . & M. & 38 & $\begin{array}{l}\text { July } 28 \\
\text { Aug. } 9\end{array}$ & $\begin{array}{l}0 \\
+\end{array}$ & $\begin{array}{c}0 \\
++\end{array}$ & $\overline{ \pm}$ & $\bar{t}$ & $\begin{array}{l}0 \\
1: 16\end{array}$ & $\begin{array}{c}0 \\
1: 2\end{array}$ & $\begin{array}{c}0 \\
1,000,000\end{array}$ \\
\hline F. W... & M. & 68 & $\begin{array}{l}\text { July } 28 \\
\text { Aug. } 9\end{array}$ & $\begin{array}{l}\mathbf{0} \\
\mathbf{0}\end{array}$ & $\begin{array}{l}0 \\
+\end{array}$ & $\overline{0}$ & $\bar{t}$ & $\begin{array}{l}1: 2 \\
1: 4\end{array}$ & $\begin{array}{l}1: 2 \\
1: 2\end{array}$ & $\begin{array}{l}10,000 \\
10,000\end{array}$ \\
\hline J. J. . & M. & 70 & $\begin{array}{l}\text { July } 29 \\
\text { Aug. } 9\end{array}$ & $\begin{array}{l}++ \\
+\end{array}$ & $\begin{array}{l}0 \\
+\end{array}$ & $\overline{ \pm}$ & $\overline{0}$ & $\begin{array}{c}0 \\
1: 32\end{array}$ & $\begin{array}{l}\mathbf{0} \\
\mathbf{0}\end{array}$ & $\begin{array}{c}100,000 \\
10,000,000\end{array}$ \\
\hline A. D... & M. & 46 & $\begin{array}{l}\text { July } 29 \\
\text { Aug. } 9\end{array}$ & $\begin{array}{l} \pm \\
0\end{array}$ & + & $\overline{0}$ & $\overline{0}$ & $\begin{array}{l}\mathbf{0} \\
\mathbf{0}\end{array}$ & $\begin{array}{l}\mathbf{0} \\
\mathbf{0}\end{array}$ & $\begin{array}{c}0 \\
1,000\end{array}$ \\
\hline J. C... & M. & 46 & $\begin{array}{l}\text { July } 28 \\
\text { Aug. } 9\end{array}$ & $\begin{array}{l}\mathbf{0} \\
\mathbf{0}\end{array}$ & $\begin{array}{l}0 \\
+\end{array}$ & $\overline{0}$ & $\overline{0}$ & $\begin{array}{c}0 \\
1: 2\end{array}$ & $\begin{array}{l}1: 4 \\
1: 2\end{array}$ & $\stackrel{0}{100,000}$ \\
\hline M. McN. & F. & 58 & $\begin{array}{l}\text { July } 30 \\
\text { Aug. } 9\end{array}$ & $\overline{0}$ & $\overline{0}$ & $\begin{array}{l}0 \\
+\end{array}$ & $\begin{array}{c}0 \\
++\end{array}$ & $\begin{array}{l}0 \\
0\end{array}$ & $\begin{array}{c}0 \\
1: 16\end{array}$ & $\begin{array}{l}0 \\
0\end{array}$ \\
\hline V. L.... & F. & 60 & $\begin{array}{l}\text { July } 30 \\
\text { Aug. } 9\end{array}$ & $\overline{ \pm}$ & $\overline{0}$ & $\begin{array}{c}0 \\
++\end{array}$ & $\begin{array}{l}0 \\
+\end{array}$ & $\begin{array}{l}\mathbf{0} \\
\mathbf{0}\end{array}$ & $\begin{array}{c}0 \\
1: 4\end{array}$ & $\begin{array}{l}\mathbf{0} \\
\mathbf{0}\end{array}$ \\
\hline M. D... & M. & 36 & $\begin{array}{l}\text { July } 29 \\
\text { Aug. } 9\end{array}$ & $\overline{0}$ & $\overline{0}$ & $\begin{array}{l}0 \\
0\end{array}$ & $\begin{array}{l}\mathbf{0} \\
\mathbf{0}\end{array}$ & $\begin{array}{l}0 \\
0\end{array}$ & $\begin{array}{c}0 \\
1: 4\end{array}$ & $\begin{array}{l}10 \\
10\end{array}$ \\
\hline H. S. . & M. & 68 & $\begin{array}{l}\text { July } 30 \\
\text { Aug. } 10\end{array}$ & $\bar{t}$ & $\overline{0}$ & $\begin{array}{l}0 \\
+\end{array}$ & $\begin{array}{l}\mathbf{0} \\
\mathbf{0}\end{array}$ & $\begin{array}{l}0 \\
0\end{array}$ & $\begin{array}{l}\mathbf{0} \\
\mathbf{0}\end{array}$ & $\begin{array}{l}0 \\
0\end{array}$ \\
\hline E. S.... & M. & 24 & $\begin{array}{l}\text { July } 29 \\
\text { Aug. } 10\end{array}$ & $\bar{t}$ & $\overline{0}$ & $\begin{array}{l}0 \\
0\end{array}$ & $\begin{array}{l}0 \\
0\end{array}$ & $\begin{array}{l}1: 2 \\
1: 4\end{array}$ & $\begin{array}{c}0 \\
1: 2\end{array}$ & $\begin{array}{l}10,000 \\
10,000\end{array}$ \\
\hline F. F.. & M. & 78 & $\begin{array}{l}\text { July } 29 \\
\text { Aug. } 10\end{array}$ & $\overline{0}$ & $\bar{t}$ & $\begin{array}{l}\mathbf{0} \\
0\end{array}$ & $\begin{array}{l}\mathbf{0} \\
\mathbf{0}\end{array}$ & $\begin{array}{l}\mathbf{0} \\
\mathbf{0}\end{array}$ & $\begin{array}{c}0 \\
1: 4\end{array}$ & $\begin{array}{l}0 \\
10\end{array}$ \\
\hline w. J.... & M. & 37 & $\begin{array}{l}\text { July } 30 \\
\text { Aug. } 9\end{array}$ & $\bar{t}$ & $\overline{ \pm}$ & $\begin{array}{l}0 \\
0\end{array}$ & $\begin{array}{l}\mathbf{0} \\
\mathbf{0}\end{array}$ & $\begin{array}{l}\mathbf{0} \\
\mathbf{0}\end{array}$ & $\begin{array}{l}\mathbf{0} \\
0\end{array}$ & $\begin{array}{l}\mathbf{0} \\
\mathbf{0}\end{array}$ \\
\hline
\end{tabular}

* No intracutaneous tests.

† See Table II for explanation of symbols.

The results of all the tests are summarized in Table VI.

\section{Single skin tests in normal subjects}

Tests with $0.01 \mathrm{mgm}$. of each of the preparations were made in 25 other subjects not listed in the previous tables. Each subject was tested with one of the preparations and the serum tested for the homologous antibody. The results are summarized in Table VII. There was no correlation between the positive tests and the corresponding antibody.

\section{DISCUSSION}

The various studies previously cited indicate that in human subjects, just as in animal experiments, significant differences may be observed in the response to injections of polysaccharides derived in different ways from the same type of pneumococcus, and, conversely, preparations which differ chemically and immunologically may elicit similar responses in human subjects ( $c f .9$, 12).

The materials used in the present study were obtained by methods designed to avoid the use of 
TABLE VI

Resumé of local reactions and circulating antibodies resulting from injection of 5 polysaccharides

\begin{tabular}{|c|c|c|c|c|c|c|c|c|c|c|c|c|c|c|c|c|c|c|}
\hline \multirow{2}{*}{\multicolumn{2}{|c|}{ Material }} & \multirow[b]{3}{*}{$\begin{array}{l}\text { 䓪 } \\
\text { 要 }\end{array}$} & \multirow[b]{3}{*}{ 苟 } & \multirow[b]{3}{*}{ 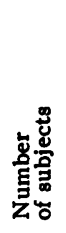 } & \multicolumn{4}{|c|}{ Local reactions * } & \multicolumn{7}{|c|}{ Homologous antibody response $\dagger$} & \multirow{2}{*}{\multicolumn{3}{|c|}{$\begin{array}{l}\text { Heterologous } \\
\text { antibody }\end{array}$}} \\
\hline & & & & & \multicolumn{2}{|c|}{ Initial } & \multicolumn{2}{|c|}{ Subsequent } & \multicolumn{3}{|c|}{ Agglutinins } & \multicolumn{4}{|c|}{ Protection } & & & \\
\hline 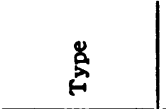 & 总 & & & & 芯 & 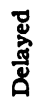 & 焉 & 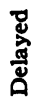 & 0 & 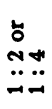 & $\begin{array}{l}+ \\
\infty \\
\ddot{-}\end{array}$ & 0 & 。요 & ㄴㅇㅇㅇ & & 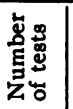 & 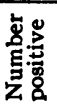 & $\stackrel{\Delta}{\not}$ \\
\hline I...... & 14 & $\begin{array}{l}1.0 \\
0.01\end{array}$ & $\begin{array}{l}\text { s.c. } \\
\text { i.c. }\end{array}$ & $\begin{array}{l}4 \\
6\end{array}$ & 3 & $\begin{array}{l}3 \\
1\end{array}$ & $\begin{array}{l}4 \\
1 \ddagger\end{array}$ & $\begin{array}{l}2 \\
0\end{array}$ & $\frac{1}{5}$ & $\begin{array}{l}3 \\
0\end{array}$ & $\begin{array}{l}0 \\
1\end{array}$ & $\begin{array}{l}0 \\
2\end{array}$ & $\begin{array}{l}\mathbf{0} \\
\mathbf{3}\end{array}$ & $\begin{array}{l}1 \\
0\end{array}$ & $\begin{array}{l}3 \\
1\end{array}$ & $\begin{array}{l}6 \\
4\end{array}$ & $\begin{array}{l}0 \\
0\end{array}$ & \\
\hline V..... & 7 & $\begin{array}{l}1.0 \\
0.01 \\
0.01\end{array}$ & $\begin{array}{l}\text { s.c. } \\
\text { i.c. } \\
\text { i.c. }\end{array}$ & $\begin{array}{l}5 \\
6 \\
58\end{array}$ & $\begin{array}{l}3 \\
3\end{array}$ & $\begin{array}{l}3 \\
2 \\
2\end{array}$ & $\begin{array}{l}3 \\
0\end{array}$ & $\begin{array}{l}2 \\
0\end{array}$ & $\begin{array}{l}3 \\
6 \\
5\end{array}$ & $\begin{array}{l}1 \\
0 \\
0\end{array}$ & $\begin{array}{l}1 \\
0 \\
0\end{array}$ & $\begin{array}{l}2 \\
1 \\
2\end{array}$ & $\begin{array}{l}2 \\
2 \\
1\end{array}$ & $\begin{array}{l}1 \\
1 \\
2\end{array}$ & $\begin{array}{l}0 \\
2 \\
0\end{array}$ & $\begin{array}{l}8 \\
5\end{array}$ & $\begin{array}{l}\mathbf{0} \\
\mathbf{0}\end{array}$ & \\
\hline VII $\ldots \ldots$ & 7 & $\begin{array}{l}1.0 \\
0.1\end{array}$ & $\begin{array}{l}\text { s.c. } \\
\text { i.c. }\end{array}$ & $\begin{array}{l}5 \\
5\end{array}$ & 4 & $\begin{array}{l}5 \\
1\end{array}$ & $\begin{array}{l}5 \\
2\end{array}$ & $\begin{array}{l}2 \\
1\end{array}$ & $\frac{1}{5}$ & $\begin{array}{l}1 \\
0\end{array}$ & $\begin{array}{l}3 \\
0\end{array}$ & 4 & 1 & $\mathbf{0}$ & $\mathbf{0}$ & $\begin{array}{r}10 \\
5\end{array}$ & $\begin{array}{l}\mathbf{0} \\
\mathbf{0}\end{array}$ & \\
\hline IV ..... & 1 & $\begin{array}{l}1.0 \\
0.01 \\
0.01\end{array}$ & $\begin{array}{l}\text { s.c. } \\
\text { i.c. } \\
\text { i.c. }\end{array}$ & $\begin{array}{l}5 \\
6 \\
5 \|\end{array}$ & $\begin{array}{l}2 \\
4\end{array}$ & $\begin{array}{l}5 \\
1 \\
1\end{array}$ & $\begin{array}{l}2 \\
3\end{array}$ & $\begin{array}{l}2 \\
6\end{array}$ & $\begin{array}{l}1 \\
1 \\
0\end{array}$ & $\begin{array}{l}1 \\
2 \\
2\end{array}$ & $\begin{array}{l}3 \\
3 \\
3\end{array}$ & $\begin{array}{l}1 \\
1 \\
0\end{array}$ & $\begin{array}{l}0 \\
1 \\
0\end{array}$ & $\begin{array}{l}1 \\
1 \\
4\end{array}$ & $\begin{array}{l}3 \\
3 \\
1\end{array}$ & $\begin{array}{r}19^{* * *} \\
6^{* *}\end{array}$ & $\begin{array}{l}1 \\
0\end{array}$ & II \\
\hline XIV ...... & 1 & $\begin{array}{l}1.0 \\
0.01 \\
0.01\end{array}$ & $\begin{array}{l}\text { s.c. } \\
\text { i.c. } \\
\text { i.c. }\end{array}$ & $\begin{array}{l}5 \\
7 \\
3\end{array}$ & $\begin{array}{l}0 \\
2\end{array}$ & $\begin{array}{l}\mathbf{0} \\
\mathbf{0} \\
0\end{array}$ & $\begin{array}{l}4 \\
3\end{array}$ & $\begin{array}{l}2 \\
2\end{array}$ & $\begin{array}{l}0 \\
2 \\
0\end{array}$ & $\begin{array}{l}2 \\
4 \\
2\end{array}$ & $\begin{array}{l}3 \\
1 \\
1\end{array}$ & & & & & $\begin{array}{r}12 \mathrm{tt} \\
7 \mathrm{tt}\end{array}$ & $\begin{array}{l}2 \\
0\end{array}$ & II, V \\
\hline
\end{tabular}

* To the initial subcutaneous or intracutaneous injection and the subsequent intracutaneous test with the same preparation.

$\dagger$ Titer acquired or increased. Antibodies listed with the subcutaneously injected subjects represent those demonstrated before any later intracutaneous injections of the same materials.

$\ddagger$ Only 3 whose initial reactions were negative were retested.

Each of these had previously received $1.0 \mathrm{mgm}$. of the same material s.c.

II After $1.0 \mathrm{mgm}$. Type XIV SSS given s.c.

I After $1.0 \mathrm{mgm}$. Type IV SSS given s.c.

** Skin tests done in 9 subjects with Type XIV SSS: 5 immediate positive and 2 delayed positive reactions.

t† Skin tests with Type IV SSS done in 12 subjects: 8 gave immediate and 3 gave delayed reactions.

heat and of chemical reagents that alter the character of the products (1). Of the 5 preparations used, 4 were specific polysaccharides of types not previously tested in human subjects, namely Types IV, V, VII, and XIV (38), and the fifth was a Type I preparation. The local reactions to initial intracutaneous injections observed with all of these preparations were similar to those observed by Finland and Dowling (9) with the socalled cellular carbohydrates. Immediate and delayed reactions occurred together or independently of one another or of the presence of homologous type-specific antibody in the circulating blood. In the small numbers of subjects tested, the intracutaneous reactions, immediate and delayed, but particularly the latter, appeared more frequently after previous injections of the same or of some other polysaccharide had been given subcutaneously than with the initial intracutaneous injection. These reactions were not associated with homologous type-specific antibodies. The findings suggest that these materials contain a nontype-specific antigen in addition to the type-specific component.

The present observations with different doses and routes of injection and similar studies of other investigators $(19,23,30,34)$ indicate that the optimum dose may vary widely with different preparations of each polysaccharide-that toxic effects or immunity may arise only within a certain range of dosage. This optimum must, therefore, be worked out with each material and for each animal species. Improper dosage, or route, or intervals may account for the irregular response obtained with some of the materials.

The antibodies demonstrated following the injection of the various specific carbohydrates used in this and in most of the other studies mentioned were almost wholly specific for the homologous type of pneumococcus. Only rare subjects de- 
TABLE VII

Results of intracutaneous tests with $0.01 \mathrm{mgm} . S S S$ and corresponding serum antibodies \&

\begin{tabular}{|c|c|c|c|c|c|}
\hline \multirow{2}{*}{ Type } & \multirow{2}{*}{$\begin{array}{c}\text { Prepara- } \\
\text { tion }\end{array}$} & \multirow{2}{*}{$\begin{array}{l}\text { Number } \\
\text { of } \\
\text { subjects }\end{array}$} & \multicolumn{2}{|c|}{ Positive reactions } & \multirow{2}{*}{$\begin{array}{l}\text { Homologous } \\
\text { antibody } \\
\text { present* }\end{array}$} \\
\hline & & & Immediate & Delayed & \\
\hline $\begin{array}{r}I \ldots \ldots \\
\operatorname{IV} \ldots \ldots \\
\operatorname{VII} \ldots \ldots \\
\text { XIV......... }\end{array}$ & $\begin{array}{r}14 \\
1 \\
7 \\
7 \\
1\end{array}$ & $\begin{array}{l}6 \\
4 \\
7 \\
5 \\
3\end{array}$ & $\begin{array}{l}2 \\
2 \\
3 \\
3 \\
0\end{array}$ & $\begin{array}{l}1 \\
0 \\
2 \\
1 \\
0\end{array}$ & $\begin{array}{l}0 \\
1 \dagger \\
2 \ddagger \\
5 \\
0\end{array}$ \\
\hline
\end{tabular}

8 Additional normal subjects not noted in Tables II to V. * Type XIV, agglutinins only, tests for both agglutinins and protective antibodies of the other types. No agglutinins found in any of the subjects.

+ Skin test positive (immediate).

$\ddagger$ One had positive immediate and delayed skin tests.

veloped immunity to other types, usually in low titer. Other workers $(30,31)$, using preparations made by various methods, obtained immunity for heterologous types. In some of their experiments, the heterologous immunity was of the same degree, and it was sometimes obtained in the absence of the homologous type response. Felton, Sutliff, and Steele (30) obtained high degrees of cross immune response to certain nonprotein fractions of Types I and II pneumococci. Some of these preparations were obtained from Dr. Felton and injected into the skin of patients recovering from Type I or Type II pneumonia. With some of these preparations, the resulting immediate reaction was type-specific and with others cross-reactions were obtained (39). Antiphagocytic and antibactericidal activity for heterologous types were also demonstrated with some of these antigens, but the other preparations of Types I and II used were active against the homologous type only and gave typical reactions only in patients with pneumonia due to the homologous type $(9,39)$. There is little doubt, therefore, that the cross-reactions are a property of the particular preparations used.

Francis (40) advocated the use of the skin test with the specific carbohydrate as a guide to serum therapy and to prognosis. This was based on the demonstration of a strict correlation between positive immediate cutaneous reactions and recovery in Type I cases. Whether this correlation can be used as a guide to dosage and prognosis in other types or whether, even in Type I cases, it will prove useful with different preparations used by other workers remains to be seen. Observations with a number of polysaccharide preparations have been carried out in specifically treated cases of several pneumococcus types. Although the tests have proved useful in some cases, the results have been confusing in others. The observations in pneumonia patients will be reported in a later communication.

\section{SUM MARY}

Type-specific polysaccharides prepared from Pneumococci Types I, IV, V, VII, and XIV were all shown to be capable of stimulating the production of homologous type-specific antibodies in human subjects.

Except for the Type XIV preparation, each gave slight to moderate local reaction in some of the subjects to whom it was given either in a 1.0 mgm. dose subcutaneously or in a $0.01 \mathrm{mgm}$. amount intracutaneously. Subsequent skin tests with each of the preparations gave a higher frequency of immediate and delayed reactions regardless of whether the previous injection was of the same or of another type.

Positive immediate cutaneous reactions to initial injection were not regularly associated with the presence of homologous type-specific antibodies in the serum.

While $1.0 \mathrm{mgm}$. subcutaneously of the Type I and Type VII preparations produced a better homologous type-specific antibody response than $0.01 \mathrm{mgm}$. of the same material given intracutaneously, this was not equally true of the other preparations used.

The technical work was carried out with the assistance of Mrs. Mildred W. Barnes.

The authors are indebted to Drs. Augustus B. Wadsworth and Rachel Brown for the supply of carbohydrates and for their kindly interest.

\section{BIBLIOGRAPHY}

1. Wadsworth, A. B., and Brown, Rachel, Chemical and immunological studies of the pneumococcus. IV. Ultrafiltration in the preparation of Type I, II, III, and atypical polysaccharides. J. Immunol., 1937, 32, 467.

2. Tillett, W. S., and Francis, T., Jr., Cutaneous reactions to the polysaccharides and proteins of pneumococcus in lobar pneumonia. J. Exper. Med., $1929,50,687$. 
3. Francis, T., Jr., and Tillett, W. S., Cutaneous reactions in pneumonia. The development of antibodies following intradermal injection of type-specific polysaccharide. J. Exper. Med., 1930, 52, 573.

4. Finland, M., and Sutliff, W. D., Specific cutaneous reactions and circulating antibodies in the course of lobar pneumonia. I. Cases receiving no serum therapy. J. Exper. Med., 1931, 54, 637.

5. Finland, M., and Sutliff, W. D., Specific cutaneous reactions and circulating antibodies in the course of lobar pneumonia. II. Cases treated with antipneumococcic sera. J. Exper. Med., 1931, 54, 653.

6. Alston, J. M., Galbraith, G. R., and Stewart, D., The soluble specific substance of Pneumococcus Type I -Antibactericidal action: Skin reactions. J. Path. and Bact. (Proc.), 1930, 33, 845.

7. Sutliff, W. D., and Finland, M., Antipneumococcic immunity reactions in individuals of different ages. J. Exper. Med., 1932, 55, 837.

8. Zozaya, J., and Clark, J., Active immunization in human cases with the polysaccharide of Pneumococcus Type I. Proc. Soc. Exper. Biol. and Med., $1932,30,44$.

9. Finland, M., and Dowling, H. F., Cutaneous reactions and antibody response to intracutaneous injections of pneumococcus polysaccharides. J. Immunol., 1935, 29, 285.

10. Alston, J. M., and Lowden, S. R., Studies of the skin reactions to the specific soluble substances of the pneumococcus Types I and II. Brit. J. Exper. Path., 1933, 14, 1.

11. Finland, M., and Sutliff, W. D., Specific antibody response of human subjects to intracutaneous injection of pneumococcus products. J. Exper. Med., 1932, 55, 853.

12. Francis, T., Jr., Antigenic action of the specific polysaccharide of Pneumococcus Type I in man. Proc. Soc. Exper. Biol. and Med., 1934, 31, 493.

13. Heidelberger, M., Sia, R. H. P., and Kendall, F. E., Specific precipitation and mouse protection in Type I antipneumococcus sera. J. Exper. Med., 1930, $52,477$.

14. Heidelberger, M., and Avery, O. T., The soluble specific substance of pneumococcus. J. Exper. Med., 1923, 38, 73.

15. Tillett, W. S., and Francis, T., Jr., Serological reactions in pneumonia with a non-protein somatic fraction of pneumococcus. J. Exper. Med., 1930, $52,561$.

16. Ash, R., Nonspecific precipitins for pneumococcic fraction $C$ in acute infections. J. Infect. Dis., 1933, 53, 89.

17. Tillett, W. S., Goebel, W. F., and Avery, O. T., Chemical and immunological properties of a species-specific carbohydrate of pneumococci. J. Exper. Med., 1930, 52, 895.

18. Francis, T., Jr., and Abernethy, T. J., Cutaneous reactions in pneumonia to the somatic (" $\mathrm{C}$ ") polysaccharide of pneumococcus. J. Clin. Invest. (Proc.), 1934, 13, 692.
Abernethy, T. J., and Francis, T., Jr., Studies on the somatic $\mathrm{C}$ polysaccharide of pneumococcus. I. $\mathrm{Cu}-$ taneous and serological reactions in pneumonia. $\mathrm{J}$. Exper. Med., 1937, 65, 59.

19. Wadsworth, A. B., and Brown, R., Chemical and immunological studies of the pneumococcus. III. Cellular carbohydrate fractions. J. Immunol., 1933, 24, 349.

20. Perlzweig, W. A., and Steffen, G. I., Studies on pneumococcus immunity. III. The nature of pneumococcus antigen. J. Exper. Med., 1923, 38, 163.

21. Ferry, N. S., and Fisher, L. W., Studies of the immunizing properties of bacterial antigens prepared after various methods. I. Brit. J. Exper. Path., 1924, 5, 185.

Idem. II. Brit. J. Exper. Path., 1924, 5, 205.

22. Day, H. B., The preparation of antigenic specific substance from streptococci and pneumococci (Type I). Brit. J. Exper. Path., 1930, 11, 164.

23. Schiemann, O., and Casper, W., Sind die spezifisch präcipitablen Substanzen der 3 Pneumokokkentypen Haptene? Ztschr. f. Hyg. u. Infektionskr., 1927-8, 108, 220.

24. Schiemann, O., Weitere Untersuchungen mit der Kohlehydrat aus Typ-II Pneumokokken. Ztschr. f. Hyg. u. Infektionskr., 1929, 110, 567.

25. Enders, J. F., A type-specific substance distinct from the specific carbohydrate in Pneumococcus Type I. J. Exper. Med., 1930, 52, 235.

Hornus, G. J. P., and Enders, J. F., Soluble specific substance of Pneumococcus Type III possessing properties distinct from SSS III. Proc. Soc. Exper. Biol. and Med., 1936, 34, 102.

26. Zozaya, J., and Clark, J., Active immunization of mice with the polysaccharides of pneumococci Types I, II, and III. J. Exper. Med., 1933, 57, 21.

27. Felton, L. D., Active immunization of white mice by a non-polysaccharide and probably non-protein derivative of the pneumococcus. J. Immunol., 1932, 23, 405.

28. Avery, O. T., and Goebel, W. F., Chemoimmunological studies on the soluble specific substance of pneumococcus. I. The isolation and properties of the acetyl polysaccharide of Pneumococcus Type I. J. Exper. Med., 1933, 58, 731.

29. Felton, L. D., and Prescott, B., The influence of acetyl group on the antigenicity of Type I pneumococcus polysaccharide. J. Bact. (Proc.), 1938, $35,31$.

30. Felton, L. D., Sutliff, W. D., and Steele, B. F., Antigenic characteristics in man of certain products of the pneumococcus. Comparison with vaccine. J. Infect. Dis., 1935, 56, 101.

31. Day, H. B., Species immunity to pneumococcus. J. Path. and Bact., 1933, 36, 77.

32. Finland, M., and Ruegsegger, J. M., Immunization of human subjects with the specific carbohydrates of Type III and the related Type VIII pneumococcus. J. Clin. Invest., 1935, 14, 829. 
33. Finland, M., and Winkler, A. W., Antibody response to infections with Type III and the related Type VIII pneumococcus. J. Clin. Invest., 1934, 13, 79.

34. Ruegsegger, J. M., and Finland, M., The influence of dosage and route of injection on the antibody response of human subjects to the specific carbohydrate of the Type VIII pneumococcus. J. Clin. Invest., 1935, 14, 833.

35. Finland, M., and Tilghman, R. C., Bacteriological and immunological studies in families with pneumococcic infections: the development of typespecific antibodies in healthy contact carriers. J. Clin. Invest., 1936, 15, 501.

36. Finland, M., and Winkler, A. W., Antibody response to infections with Type II and the related Type V pneumococcus. J. Clin. Invest., 1934, 13, 97.
37. Finland, M., Tilghman, R. C., Ruegsegger, J. M., and Dowling, H. F., Clinical and immunological observations in cases of Pneumococcus Type VII pneumonia treated with concentrated type-specific antibody. Am. J. M. Sc., 1937, 193, 59.

38. Cooper, G., Edwards, M., and Rosenstein, C., The separation of types among the pneumococci hitherto called Group IV and the development of therapeutic antiserums for these types. J. Exper. Med., 1929, 49, 461.

39. Finland, M., and Dowling, H. F., Unpublished observations.

40. Francis, T., Jr., The value of the skin test with typespecific capsular polysaccharide in the serum treatment of Type I pneumococcus pneumonia. J. Exper. Med., 1933, 57, 617. 